\title{
African Youth Utilising IT-Essentials Innovation in Re-vitalisation of PCs to Equip Disadvantaged Rural Schools Shaping their ICT Learning Landscape: Namibian Case Study
}

\author{
http://dx.doi.org/10.3991/ijet.v9i4.3560 \\ J. Mbale \\ University of Namibia, Windhoek, Namibia
}

\begin{abstract}
As the sub-Saharan region was expanding educational infrastructure, they met challenges to equip the rural schools with Personal Computers (PC's). The PC's as equipment that required frequently upgrading as technology evolved, the institutions from urban kept on replacing the outdated with the new ones that had high hardware and software specifications, such as RAM, hard-disc, CPU speed, etc. Though still functioning at an en-efficient level, the outdated PC's (o-PCs) were abandoned in some cases packed on corridors. These o-PCs were regarded as enefficient because of degraded specification as in a long run technology demanded more resources. While these urban tertiary institutions were abandoning the o-PCs, the primary and secondary schools in rural areas were completely inaccessible of PC's. At a serious note, in some remote schools, pupils had not even touched a Computer KeyBoard. These students were completely deprived of the IT/ICT technologies and services. It was against this background that the IT-Essentials students at the University of Namibia, in the Department of Computer Science, envisaged on an innovation of servicing and upgrading the abandoned o-PCs to be deployed in primary and secondary schools that were in remote areas. These refurbished PC's were deployed in targeted rural schools. In that way, these under privileged students had opportunity to experience and utilise the ICT facilities.
\end{abstract}

Index Terms-abandoned PC's packed on corridors, innovation in Re-vitalisation of $\mathrm{PCs}$, under privileged remote schools and IT-Essentials.

\section{INTRODUCTION}

The Department of Computer Science at the University of Namibia embarked on a community service project where the IT-Essential (IT-E) Students were refurbishing the abandoned computers for distribution and use by the learners from remote primary and secondary schools. These schools from rural and remote areas had no access to IT/ICT equipment such as Personal Computers (PCs). As such these learners were not privileged to acquire and utilise IT skills in their education. This was contrary to institutions in urban areas where some individual schools had acquired PC's for their students to use in shaping their IT/ICT learning landscape.

\section{A. Statement of a Problem}

A number of prevailing factors lead to the envisaging of this work. In general, the sub-Saharan tertiary institutions especially in urban areas had acquired Personal Computers (PC's) for their students to use in shaping their IT/ICT learning landscape. However, it was not the same with remote primary and secondary schools. There were a number of barriers such as, cost of computers, poor services, unavailability of IT technicians in rural schools, inaccessible of remote schools and lack of electricity infrastructure. However, Namibia was not an exception, some if not many schools in remote areas did not have PC's. The other factor which motivated this work was that the Department of Computer Science at the University of Namibia runs IT-Essentials (IT-E), a CISCO programme that train students step-by-step to assemble and service computers, and many more IT equipment. In $[1,2]$ they defined IT-E: PC Hardware and Software as a short course that provided a comprehensive introduction to the ICT industry and interactive, hands-on exposure to personal computers, hardware, software, and operating systems. They further explained that it covered the internal components of a computer, assemble a computer system, install an operating system, and troubleshoot using system tools and diagnostic software.

Hence, upon the Department realising the potential of the IT-E group to assemble and repair, they collected all the PCs that were piled on the corridors stored them unto the IT-E dedicated laboratory. The IT-E group started repairing, assembling and servicing the collected PCs. As a number of refurbished PCs were increasing, this motivated the Department to realise assisting the disadvantaged rural schools who had no access to IT equipment particularly the PCs. Hence, the Department utilised the expertise of the IT-E group to repair, refurbish, upgrade and service the old and abandoned PCs.

It was in view of the above discussed factors that motivated the Department to envisage such a community service as the Youth's obligation to answer the country's (Namibia) 2030 Vision to industrialise its industry across its regions. The Report [3] pointed out that the Namibian Government as identified in Vision 2030 that ICT skills and competencies were core elements of living and participating in the $21^{\text {st }}$ century. The Report further highlighted second and third priorities as deployment of ICT services and strengthen education management through the use of 
ICTs respectively. Through this vision, I-TE group thought as an advantaged sector, it was their mandate and privilege to assist their Government to take the ICT resources such as PC's to the needy community, in this case the disadvantaged primary and secondary schools that were in remote areas to give pupils access to IT/ICT facilities.

\section{B. Organisation of the Paper}

Section I introduced the factors that lead to motivation of the project. It explained the statement of the problem by highlighting the utilization of availability of the abandoned IT resources still functioning and human capacity, who were the IT-E group. Some of the organisations in the world involved with refurbishing PCs and distributing to the need communities of sub-Saharan region were discussed in Section II. The teaching programme of the ITEClass was described in Section III, paying much emphases on skill transfer. Section IV discussed the whole operation of repairing and upgrading the PCs. The conclusion of the study was given in Section $\mathrm{V}$.

In that work, it is important to point out that the value, costs or prices of the resources used as compared to present it is low due to the fact that the project was conducted end of 2012 and mid 2013. Even some resources and technologies used are now old, for instance Office 2010.

\section{LITERATURE REVIEW}

Many scholars have written on the second-hand or refurbished computers for deployment and use in the subSaharan rural schools that were disadvantaged with such equipment. In [4], he pointed out that for many poorer schools and countries the option of buying new computers was prohibitively expensive. He said using second hand computers could be a practical and affordable alternative. $\mathrm{He}$ also expressed that, while such equipment was not the latest and most powerful in computing terms it could still be functional for educational purposes as such, to do that, the latest hardware and software was not needed. His clarification here was that learning how to learn about ICT did not need the latest equipment. In addition, he discussed that in ICT education, students needed to acquire a range of skills, including how to learn about different software packages. He stressed that most students would need to learn how to use new application before they reach the labour force. He further cited several None Governmental Organisation (NGOs) that had been established in Europe and America to recycle computers to developing countries such as: the Computer Aid International based in United Kingdom (UK), the Afritech from Canada and the WorLD Organisation hosted in Washington of United State of America (USA).

In $[5,6,7]$ they discussed that computers and computer resources were indispensable in the educational and business environment today. They stressed that it was very difficult for someone who was not computer literate to successfully complete his or her tertiary studies or find gainful employment. They also emphasized that most jobs in the business world required some knowledge of the use of computers and the Internet. They further pointed out that, in most rural schools it was unlikely that you would find a computer laboratory, yet alone someone with knowledge of the Internet, unlike urban schools. Also, they highlighted that yet the Internet could be used to bridge the gap between rural and urban schools. They went ahead to stress that computer and its resources were central to modern education and it was here to stay.

In $[8,9]$ they pointed out that in Africa, the introduction of computers into primary and secondary education is a recent phenomenon. High subscription and ICT infrastructure costs coupled with the poor quality of service providers and the lack of basic infrastructure such as electricity can act as barriers to the use of ICT in education. However in $[10,11,12,13,14]$ they narrated that there was evidence that the use of ICT could reduce the disadvantages that remote schools suffer.

\section{IT-E CLASS}

The IT-E group was applying their knowledge they learnt in IT-E: PC Hardware and Software class (Figure 1) an industrial hands on short course that dealt with fixing and servicing PCs, laptops, printers, scanners, projectors and photo-copying machines. In [15] they described IT-E as hands-on, career oriented e-Learning solution with an emphasis on practical experience to help students develop fundamental computer skills, along with essential career skills. They further highlighted several features and benefits offered by the IT-E as follows: first, students developed knowledge of how computers operate, how to assemble computers, and how to troubleshoot hardware and software issues. Second, was hands-on labs and virtual learning tools help students develop critical thinking and complex problem-solving skills. Third, the course emphasized the practical application of skills and procedures needed for hardware and software installations, upgrades, and troubleshooting systems. Fourth, the Cisco Packet Tracer simulation-based learning activities promoted the exploration of networking and network security concepts and allow students to experiment with network behaviour. Last but not least, interactive assessments provided immediate feedback to support the evaluation of knowledge and acquired skills.

In view of the above, during the lessons, the IT-E students were taught how computers operate and how to assemble all necessary spare parts ranging from mother board, CPU, fun, cables, power supply, jumpers, graphic cards, network cards, hard drives, cd drives, memory cards, etc. The students were taught how to install many kinds of operating and application software. The learners were involved in troubleshooting the installed systems. Also, the students were taught how to use the Cisco Packet Tracer to simulate the setting and configuring of the network.

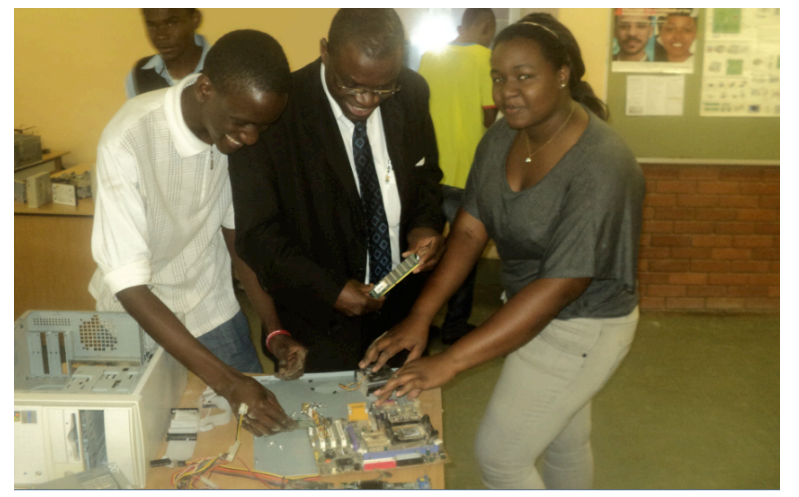

Figure 1. IT-Essential: PC Hardware and Software Class 


\section{IMPLEMENTATION OF THE PROJECT}

With that kind of knowledge of IT Essentials, the IT-E group bought enough new computer spare parts shown in Table 1. The RAM shown in Figure 2 and Hard Drive were the most required spare parts for upgrading the outdated PCs, in that work was abbreviated as "o-PCs". For a start, the group collected eighty (80) PCs for the project. In that case, they were compelled to also buy eighty (80) of RAM and Hard Drive equivalent to the o-PCs. The rest of spare parts only those found on the o-PCs that were not functioning, for instance, from Table 1, about five CPU, thirty (30) Mouse, twenty seven (27) keyboards, twenty four (24) DVD Writers and some assorted Fans were not functioning. In that case, and in addition to the mandatory ones the RAMs and Hard Drives, the IT-E group bought the other parts that were not working. They also bought the software Office 2010. The prices for these spare parts are shown in Table 1.

The total amount for these o-PCs spare parts was Namibian Dollars One Hundred and Twelve Thousand, Six Hundred and Twenty Two and Seventy Five Shillings (N\$ 112,622.75). The price in Table 2 of a brand new PC was taken and Eighty (80) of them would have cost Namibian Dollars Seven Hundred Sixty Eighty Seven Hundred Eighty Seven Thousand and Twenty Shillings (N\$ 768,787.20). From the latest PCs prices Table 2, and the upgrading costs, the difference came to Namibian Dollars, Six Hundred Fifty Six, One Hundred and Sixty Four Thousand and Forty Five Shillings (N\$656,164.45), all this was the money through innovation, the Youth helped through rendering their services.

In comparison, the difference between new PCs and the upgraded ones was Six Hundred Fifty Seven and One Hundred and Seventy Four and Ninety Five Shillings (N\$ $657,174.95)$, and this was the amount the students helped the Institution, by envisaging an innovation of saving the huge costs. Such a difference would have cost the Institutions a lot of money. However, the original price of the oPCs shown in Table 3 was Three Thousand, Five Hundred Namibian Dollars (N\$3,500.00) per equipment. The eighty (80) of them cost Two Hundred Eighty Thousand Namibian Dollars (N\$280,000.00). The cost of upgrading the eighty (80) o-PCs, came to N\$ $112,622.75$ as shown in Table 1.

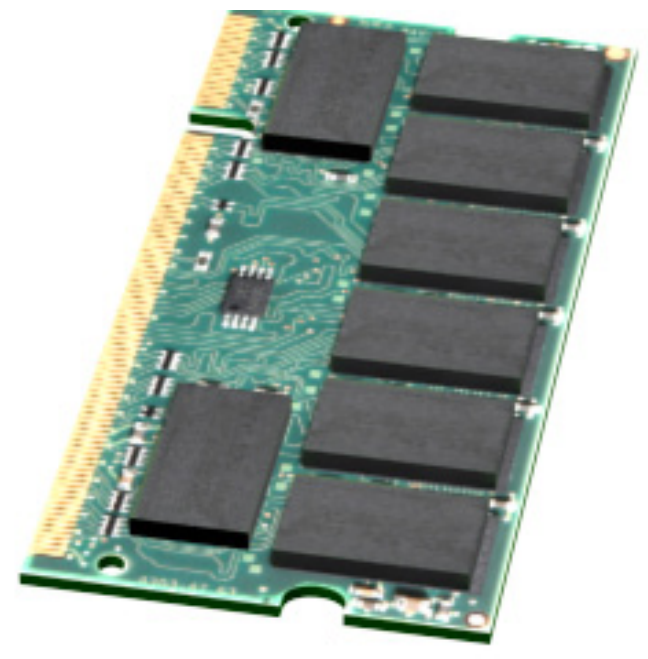

Figure 2. RAM
TABLE I.

PC SPARE PARTS FOR UPGRADING

\begin{tabular}{|c|c|c|c|c|c|}
\hline & Description & Specification & $\begin{array}{l}\text { Price Per } \\
\text { Item (N\&) }\end{array}$ & Qnty & $\begin{array}{l}\text { Total Price } \\
(\mathrm{N \&})\end{array}$ \\
\hline \multicolumn{6}{|c|}{ Hardware } \\
\hline 1 & RAM & $\begin{array}{l}\text { Memory 1025MB } \\
\text { DDR3 240-Pin } \\
\text { DIMM, 1.5V }\end{array}$ & 336.00 & 80 & $26,880.00$ \\
\hline 2 & HDD & $\begin{array}{l}\text { SATA (500GB) } \\
6 \mathrm{~GB} / \mathrm{S} 16 \mathrm{MB} \\
\end{array}$ & 781.25 & 80 & $62,500.00$ \\
\hline 3 & $\mathrm{CPU}$ & $\begin{array}{l}\text { Intel CPU, Core i5 } \\
\text { Range }\end{array}$ & $2,048.75$ & 5 & $10,243.75$ \\
\hline 4 & $\begin{array}{l}\text { Optical } \\
\text { Mouse }\end{array}$ & $\begin{array}{l}200 \mathrm{Mac} / \mathrm{Win} \text { USB } \\
\text { - Black }\end{array}$ & 86.00 & 30 & $2,580.00$ \\
\hline 5 & Keyboard & $\begin{array}{l}\text { Microsoft Wired } \\
200 \text { USB Black }\end{array}$ & 118.00 & 27 & $3,186.00$ \\
\hline 6 & DVD Writer & $\begin{array}{l}\text { Samsang DVD } \\
\text { SATA Retail }\end{array}$ & 193.00 & 24 & $4,632.00$ \\
\hline 7 & $\begin{array}{l}\text { Fans (CPU, } \\
\text { Power Supply } \\
\text { \& Video } \\
\text { Card) } \\
\end{array}$ & & & & $1,000.00$ \\
\hline \multicolumn{6}{|c|}{ Software } \\
\hline 8 & Office 2010 & & $1,600.50$ & & $1,600.50$ \\
\hline \multicolumn{5}{|c|}{ Total } & $112,622.75$ \\
\hline
\end{tabular}

TABLE II.

LATEST PCS SPECIFICATION AND PRICES

\begin{tabular}{|c|c|c|c|c|c|}
\hline & $\begin{array}{l}\text { Descrip } \\
\text { scrip- } \\
\text { tion }\end{array}$ & Specification & $\begin{array}{l}\text { Price Per } \\
\text { Item (N\&) }\end{array}$ & Qnty & $\begin{array}{l}\text { Total Price } \\
(\mathrm{N \&})\end{array}$ \\
\hline 1 & $\mathrm{PC}$ & $\begin{array}{lrr}\text { HP } & \text { Compaq } & 6300 \text { Pro } \\
\text { MT } & \text { i5-3470(3.2-GHz, } \\
6 \mathrm{MB} & \text { L2 } & \text { cache), } \\
4 \mathrm{~GB}(2 \times 2 \mathrm{~GB}) & \text { DDR3- } \\
1600 & -500 \mathrm{~GB}, & \text { HDD - } \\
\text { DVD+/-RW } & \text { SuperMulti, } \\
\text { Windows } 7 & \text { Pro } 64 \mathrm{bit}, \\
\text { Office 2010. } \\
\text { HP 2311x23" LED LCD } \\
\text { Monitor }\end{array}$ & $9,609.84$ & 80 & $768,787.20$ \\
\hline
\end{tabular}

TABLE III.

OLD PCS SPECIFICATION AND PRICES

\begin{tabular}{|l|l|l|r|r|l|}
\hline $\begin{array}{l}\text { Descrip- } \\
\text { tion }\end{array}$ & Specification & $\begin{array}{l}\text { Price Per } \\
\text { Item (N\&) }\end{array}$ & Qnty & $\begin{array}{l}\text { Total Price } \\
\text { (N\&) }\end{array}$ \\
\hline 1 & PC & $\begin{array}{l}\text { Pentium 4, HDD } \\
\text { 40GB, CPU 1.6GHz, } \\
\text { RAM 512MB }\end{array}$ & $3,500.00$ & 80 & $280,000.00$ \\
\hline
\end{tabular}

The difference from the old and upgraded o-PCs was Namibian Dollars One Hundred Sixty Seven Thousand Three Hundred and Seventy Seven and Twenty Five Shillings. This difference showed the money the Institution would have incurred as overhead costs.

Figure 3 gives a summary of costs of the equipment: of old PCs with the lower specifications, the current PCs with the higher specifications and the upgraded PCs. From the figure, it was clear that it would have costed the tertiary Institution about Namibian Dollars Seven Hundred Sixty Eighty Seven Hundred Eighty Seven Thousand and Twenty Shillings (N\$768,787.20). However, with the Youth's innovative engagement, they served the Institution from parting away with the sum of Namibian Dollars, Six Hundred Fifty Six, One Hundred and Sixty Four 


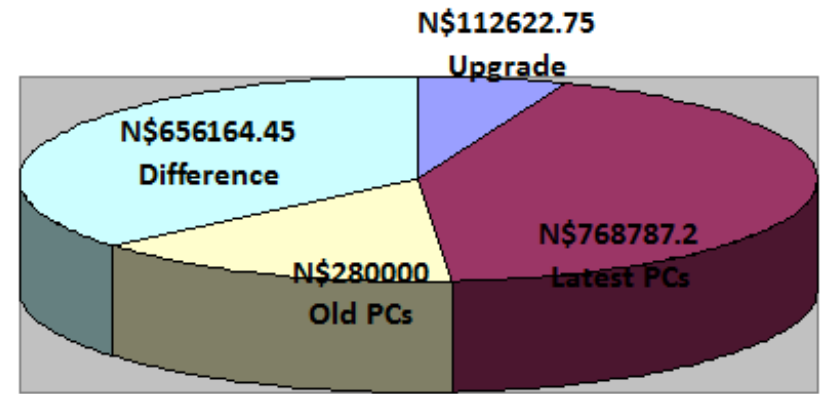

Figure 3. IT-Essential: PC Hardware and Software Class

Thousand and Forty Five Shillings (N\$656,164.45). The Youth's engagement innovation served as cost-serving measures on the re-cycling of the out-dated equipment. The o-PCs were rejuvenated to acquire the high level specification of the equipment which attained an efficient operation expected standard.

\section{CONCLUTION}

In order to manage supply the PC's to the disadvantaged rural schools, the IT-E group utilised the following: first, the availability of abandoned and packed PC's on the corridors that were still functioning. The group collected the abandoned PC's and carried out necessary repairs. They also upgraded the memory size from 1MGB to 4MGB for each refurbished PC. For them to have accomplished such tasks, they applied the knowledge they were taught in IT-E class. Third, the group was motivated by the call for vision 2030, which was emphasising on the attainment of $21^{\text {st }}$ century skills that were stipulated in the second and third priorities as deployment of ICT services and strengthen education management through the use of ICTs respectively. Fourth, the group was encouraged by one of the institution's mandatory goals, which was, community service outreach, an additional from teaching and research. The group felt honoured and empowered to render constructive services to the disadvertanged communities, such as students from remote and rural schools.

\section{ACKNOWLEDGMENT}

To acknowledge the support rendered by Telecom Namibia.

\section{REFERENCES}

[1] http://www.cisco.com/web/learning/netacad/course_catalog/docs/ Cisco_ITE_AAG.pdf

[2] http://www.cisco.com/web/learning/netacad/course_catalog/docs/ Cisco_ITE_DS.pdf
[3] Education and Training Sector Improvement Programme (ETSIP), 2006

[4] Andy Cawthera. Computers in secondary schools in developing countries: costs and other issues. The Department for International Development (DFID), World Links for Development (WorLD): a part of the World Bank Institute, The Human Development Network of the World Bank, 2001. http://ageconsearch.umn.edu/ bitstream/12831/1/er010043.pdf

[5] ME Herselman. ICT in Rural Areas in South Africa: Various Case Studies. Informing Science InSITE - "Where Parallels Intersect" June 2003. proceedings.informingscience.org/IS2003Proceedings/ docs/120Herse.pdf

[6] Furlonger, D. (2002, January 25.) Rally to read. Retrieved 4 June 2002 from http://free.financialmail.co.za/rallytoread/rally.htm

[7] Solar Powered Schools in South Africa: Solar Electric Light Fund. (2001) Retrieved 23 July 2002 from http://www.self.org/ sou_africa/solarschools.asp

[8] Nomsa Mndzebele. Challenges Faced by Schools when Introducing ICT in Developing Countries. International Journal of Humanities and Social Science Invention ISSN (Online): 2319 - 7722, ISSN (Print): 2319 - 7714 www.ijhssi.org Volume 2 Issue 9\| September. 2013\| PP.01-04 www.ijhssi.org 1 | Page

[9] F. M. Ihmeideh, Barriers to the Use of Technology in Jordanian Pre-school Settings, Technology, Pedagogy and Education, 18(3), 2009, 325-341. http://dx.doi.org/10.1080/14759390903255619

[10] Bruce White. Using ICT to enhance curriculum opportunities for students in rural and remote schools. Australian Educational Computing Volume 25, number 2, December 2010

[11] Trinidad, S. (2006). Closing the digital divide: Education telecommunications systems and possibilities in Western Australia. Australian Computers in Education Conference (ACEC 2006) up there for thinking, Cains, ACCE.

[12] White, B., \& Johnston, S. (2008). The impact of using social computing tools to teach physics across two campuses. In Australian Computers in Education Conference: Conference Proceedings. Canberra, Australia: Australian Council for Computers in Education, pp 626-631.

[13] Anastasiades, P. S., \& Filippousis, G. (2010) Interactive Videoconferencing for collaborative learning at a distance in the school of 21st century: A case study in elementary schools in Greece. Computers \& Education 54(2), pp 321-339. http://dx.doi.org/10.1016/j.compedu.2009.08.016

[14] Trinidad, 2006, White \& Johnston, 2008, Reading, 2009, Anastasiades \& Filippousis, 2010

[15] CISCO Course Catalog: http://www.cisco.com/web/learning/ netacad/course_catalog/IT1.html

\section{AUTHORS}

J. Mbale is with University of Namibia, Centre of Excellence in Telecommunications (CoE), Department of Computer Science, Private Bag 13301, Windhoek, Namibia (e-mail: mbalej@yahoo.com).

This work was supported in part by I-TECH and University of Namibia. Submitted, February, 10, 2014. Published as resubmitted by the author 14 June 2014. 